\title{
Structural rearrangement and change of cerium valence in cerium dioxide $\left(\mathrm{CeO}_{2}\right)$ nanocrystals
}

\author{
Yu.I.Boyko' ${ }^{1}$, V.V.Seminko ${ }^{2}$, P.O.Maksimchuk ${ }^{2}$, Yu.V.Malyukin ${ }^{2}$ \\ ${ }^{1}$ V.Karazin Kharkiv National University, 4 Svobody Sq., \\ 61077 Kharkiv, Ukraine \\ ${ }^{2}$ Institute for Scintillation Materials, STC "Institute for Single Crystals", \\ National Academy of Sciences of Ukraine, \\ 60 Nauky Ave., 61001 Kharkiv, Ukraine
}

\section{Received June 9, 2015}

For $\mathrm{CeO}_{2}$ nanocrystals a large number of cerium ions undergo $\mathrm{Ce}^{4+} \rightarrow \mathrm{Ce}^{3+}$ transition leading to formation of oxygen-deficient $\mathrm{CeO}_{2-x}$ phase in the subsurface layer of nanocrystal. Such structural rearrangement leads to density gradient in ceria nanocrystals changing thereby the elastic constants of material. The analysis of free energy balance has shown that formation of highly deficient $\mathrm{CeO}_{2-x}$ phase occurs inevitably for the nanocrystals with sizes $d \leq 6 \mathrm{~nm}$.

Keywords: nanocrystals, $\mathrm{CeO}_{2}$, density gradient.

Для нанокристаллов $\mathrm{CeO}_{2}$ значительная часть ионов церия переходит из $\mathrm{Ce}^{4+}$ в $\mathrm{Ce}^{3+}$, что приводит $к$ формированию дефицитной по кислороду фазы $\mathrm{CeO}_{2-x}$ в приповерхностном слое нанокристалла. Подобная структурная перестройка приводит к возникновению градиента плотности, изменяя таким образом упругие постоянные материала. Анализ баланса свободной энергии показал, что формирование фазы $\mathrm{CeO}_{2-x}$ происходит для нанокристаллов с размерами $d \leq 6$ нм.

Структурна перебудова та зміна валентності церію у нанокристалах діоксиду церію. Ю.І.Бойко, В.В.Селінько, П.О.Максимчук, Ю.В. Малюкін.

Для нанокристалів $\mathrm{CeO}_{2}$ значна частина іонів церію переходить з $\mathrm{Ce}^{4+}$ у $\mathrm{Ce}^{3+}$, що призводить до формування дефіцитної за киснем фази $\mathrm{CeO}_{2-x}$ у приповерхневому шарі нанокристала. Подібна структурна перебудова призводить до появи градієнту густини, змінюючи таким чином пружні сталі матеріалу. Аналіз балансу вільної енергії показав, що формування фази $\mathrm{CeO}_{2-x}$ відбувається для нанокристалів з розмірами $d \leq 6$ нм.

\section{Introduction}

Nowadays a lot of attention is devoted to the investigation of physical properties of nanocrystals with sizes $\approx 1 \div 10 \mathrm{~nm}$ [1-4]. Both experimental and theoretical studies have shown that physical properties of nanocrystals with such sizes differ sufficiently from the properties of corresponding bulk crystals.
Cerium dioxide $\left(\mathrm{CeO}_{2}\right)$ nanocrystals are of special interest due to the number of unique properties making these nanocrystals suitable for creation of unequalled chemical catalysts, fuel cells, biological and medical antioxidants [5-8].

Remarkable properties of cerium dioxide nanocrystals are determined by changes of the crystal structure for the nanocrystals as compared to their bulk counterparts. For 
instance, in [9], using high resolution transmission electron microscopy (TEM) the linear 1D clusters of anion vacancies were revealed for $\mathrm{CeO}_{2}$ nanoparticles with sizes $\leq 6 \mathrm{~nm}$. Despite formation of such clusters the symmetry of ceria unit cell is preserved. These defects are located in the most closely packed (111) crystallographic planes.

Methods of optical spectroscopy [10-12] have shown that for ceria nanocrystals with sizes of $10 \mathrm{~nm}$ and less, specific luminescence band determined by $5 d \rightarrow 4 f$ transitions of $\mathrm{Ce}^{3+}$ ion was observed. Presence of this luminescence band indicates that part of $\mathrm{Ce}^{4+}$ ions in $\mathrm{CeO}_{2}$ nanoparticles undergoes $\mathrm{Ce}^{4+} \rightarrow \mathrm{Ce}^{3+}$ transition. Such luminescence was never observed for the bulk ceria crystals.

Such changes of the crystal structure and oxidation state of cerium ions in $\mathrm{CeO}_{2}$ nanocrystals are the main factors determining the unique properties of this material.

This paper is devoted to analysis of the causes leading to rearrangement of the crystal structure with simultaneous change of cerium valence in $\mathrm{CeO}_{2}$ nanocrystals; the theoretical calculation confirms that this concept is reasonable from viewpoint of thermodynamics.

\section{Modification of structure and cerium oxidation state in $\mathrm{CeO}_{2}$ nanocrystals}

Cerium dioxide crystals are ionic compounds with ratio of ionic radii $\approx 0.77$ and closely packed fluorite-type structure [13]. In such a structure cerium ions form facecentered cubic lattice, while oxygen ions are located in the centers of eight small cubes into which the unit cell can be divided. So, each cerium ion is surrounded by eight oxygen ions located in the cube vertices, while each oxygen ion is surrounded by four cerium ions located in the tetrahedron vertices. Such crystallographic structure corresponds to the closest packing of cerium and oxygen ions in (111) planes and also provides electroneutrality of the crystal.

For ceria nanocrystals the size of nanocrystal decrease leads to the structural rearrangement with change of the part of $\mathrm{Ce}^{4+}$ ions to $\mathrm{Ce}^{3+}$ ones. This statement is based on the analysis of luminescence spectra. Decrease of the size of ceria nanocrystal in this case has the same effect as heat treatment in reducing atmosphere, and, as it was shown in [11], both these effects manifest itself in formation of $\mathrm{Ce}^{3+}$ luminescence bands.

Such change of the oxidation state of the cerium ion must be accompanied by additional changes of the crystal structure in order to provide electroneutrality: namely, formation of two $\mathrm{Ce}^{3+}$ ions must be accompanied by formation of one oxygen vacancy $V_{\mathrm{O}}^{++}$. Formation of the oxygen vacancies is the most energetically favorable in closely packed planes in the rows of ions with similar signs. This additional structural change leads to formation of one-dimensional vacancy clusters with pre-defined orientation. All these results are supported by experimental data [9-14].

\section{Thermodynamics of subsurface structural rearrangement in $\mathrm{CeO}_{2}$ nanocrystals}

So, in the subsurface layer of $\mathrm{CeO}_{2}$ nanocrystals the oxygen-deficient $\mathrm{CeO}_{2-x}$ phase is formed. It is evident that such a change of the structure of subsurface part of nanocrystal leads to decrease of its density i.e. "loosening" of the nanocrystal. Oxygen deficiency increases towards the surface leading to density gradient with correspondent change of elastic energy. According to thermodynamics, the new phase will be stable if the free energy of nanocrystal with density gradient will be less than the free energy of nanocrystal with uniform density. For the bulk crystal role of elastic energy connected with the density gradient in the total free energy is insufficient while only $\approx 1 \%$ atoms are located in the subsurface layer of the crystal and they cannot have any influence on the thermodynamic properties of the crystal as a whole.

We have analyzed whether the free energy of nanocrystal reaches its minimum for $\mathrm{CeO}_{2} \rightarrow \mathrm{CeO}_{2-x}$ phase transition, which is realized for $\mathrm{CeO}_{2}$ nanocrystals and is accompanied by occurrence of the density gradient. The following method was used previously during investigation of the process of the new phase formation in the thin crystal layers [15].

In our case it is required to compare the values of free energy $F_{1}$ and $F_{2}$ for two different phases: phase $1\left(\mathrm{CeO}_{2}\right.$ crystal with fluorite structure and uniform density) and phase $2\left(\mathrm{CeO}_{2-x}\right.$ nanocrystal with subsurface structure rearrangement and the density gradient). Taking into account that for the bulk crystals with the uniform density $F_{1}<F_{2}$ condition is realized, we tried to 
found the critical size $d^{*}$, for which occurrence of the density gradient makes possible existence of phase 2 , or, in other words, for which $F_{2}<F_{1}$.

Let us suppose that the nanocrystal has spherical shape with radius $d$. To take into account the density gradient the free energy must be re-written as:

$$
F(\rho)=S \int_{0}^{d}\left[f(\rho)+\alpha(d \rho / d r)^{2}\right] d r
$$

Here $S$ is nanocrystal surface area, $\rho-$ density, $f(\rho)$ - free energy density, $r$ distance from the center of nanocrystal. The second term in (1) takes into account the change of free energy due to the density gradient.

Dependence on the density gradient is described by square law because the equilibrium state has the uniform density, $\alpha$ is the coefficient which is dependent on elastic constants of the material. To determine the phase state it is required to find the minimum value of the free energy (1) at constant mass condition:

$$
M=S \int_{0}^{d} \rho(r) d r .
$$

Finding of the minimum of (1) is facilitated sufficiently by using another function $G(\rho)$ obtained through the Lagrange factor:

$$
\begin{gathered}
G(\rho)=F(\rho)-\lambda S \int_{0}^{d} \rho(r) d r= \\
=S \int_{0}^{d}\left[f(\rho)+\alpha(d \rho / d r)^{2}-\lambda \rho\right] d r .
\end{gathered}
$$

Minimization of $G(\rho)$ leads to the following equations:

$$
d f(\rho) / d \rho-2 \alpha\left[d^{2} \rho / d r^{2}\right]=\lambda
$$

with boundary conditions: $\rho(0)=\rho_{1}, d \rho / d r=0$ at $r=0$ and $\rho(d)=\rho_{2}$. We take $\rho_{2}<\rho_{1}$, while in $\mathrm{CeO}_{2}$ subsurface layer "loosening" of the crystal lattice is observed. $\rho_{1}$ is the equilibrium value of density for bulk crystal, so $f(\rho)$ can be written as:

$$
f(\rho) \approx f_{0}+\frac{1}{2} f_{1}\left[\left(\rho-\rho_{1}\right)^{2}\right] .
$$

Here $f_{0}$ is the free energy density in bulk crystal, and $f_{1}=d^{2} f(\rho) / d \rho^{2}$ at $\rho=\rho_{1}$. Solu- tions of equations (4) with account of the boundary conditions and relation (5) are rather complex. However, the asymptotical solutions for the limiting cases can be easily obtained and analyzed.

For bulk crystal, i.e. at $d \rightarrow \infty$, the free energy for both phases has the following asymptotical values: $F_{1} \approx f_{0,1}\left[M / \rho_{1}\right]$ and $F_{2} \approx f_{0,2}\left[M / \rho_{2}\right]$. Here $f_{0,1}$ and $f_{0,2}$ are free energy densities for the bulk crystals, for phase 1 and 2, correspondingly. As we have stated before, $f_{0,1}<f_{0,2}$, and taking into account that in $\mathrm{CeO}_{2} \rho_{2}<\rho_{1}$, we conclude that $F_{1}<F_{2}$ condition is satisfied, and in the bulk crystals, as it was supposed before, phase 1 is more stable.

However, for small $d$ phase 2 can become more stable $\left(F_{2}<F_{1}\right)$ if elastic constants for the phase 2 become less than ones for the phase 1 due to the density gradient. It is highly probable due to high content of oxygen vacancies and $\mathrm{CeO}_{2} \rightarrow \mathrm{CeO}_{2-x}$ transition in the subsurface layer of the ceria nanocrystals.

This condition is realized if:

$f_{0,2}-f_{0,1}<\frac{1}{2}\left\{f_{1,1}\left[\left(\rho_{1}-\rho_{2}\right)^{2}\right]-f_{1,2}\left[\left(\rho_{1}-\rho_{2}\right)^{2}\right]\right\}$.

So, according to (6), formation of the phase 2 in $\mathrm{CeO}_{2}$ nanocrystals is possible if the elastic energy gain surpasses the change of free energy in the bulk crystal at phase transition, for instance, due to temperature change.

The size $d=d^{*}$ at which $\mathrm{CeO}_{2-x}$ phase became stable can be determined from $F_{1}\left(d^{*}\right)=F_{2}\left(d^{*}\right)$ condition.

So, taking $F_{1}$ and $F_{2}$ and neglecting the second order infinitesimals, we have:

$$
d^{*} \approx\left[\left(\rho_{1}-\rho_{2}\right) / \rho_{1}\right]\left(\alpha / f_{1}\right)^{1 / 2} .
$$

Here $f_{1}=d^{2} f(\rho)^{/} d \rho^{2}$ at $\rho=\rho_{1}$. The $\left(\alpha / f_{1}\right)^{1 / 2}$ term is a mean distance at which the elastic excitation caused by local elastic deformation attenuates [16]. This deformation in our case is determined by the density gradient.

For ionic crystals: $\left(\alpha / f_{1}\right)^{1 / 2} \approx 10^{-7} \mathrm{~m}$. According to the experimental data, such phase transition is accompanied by density change $\left(\rho_{1}-\rho_{2}\right) / \rho_{1} \approx 6 \cdot 10^{-2}$ [17]. Inserting the values of $\left(\alpha / f_{1}\right)^{1 / 2}$ and $\left(\rho_{1}-\rho_{2}\right) / \rho_{1}$ to (7), we have $d^{*} \approx 6 \mathrm{~nm}$, so at $d \leq 6 \mathrm{~nm}$ $\mathrm{CeO}_{2-x}$ phase is more stable. 


\section{Conclusions}

Formation of the highly oxygen-deficient $\mathrm{CeO}_{2-x}$ phase with oxygen deficiency increasing towards the surface leads to occurrence of the density gradient and decrease of the elastic constants of $\mathrm{CeO}_{2}$ nanocrystals. As was shown from free energy balance, for $d \leq 6 \mathrm{~nm}$ this phase becomes more stable than $\mathrm{CeO}_{2}$ phase with uniform density. This fact is supposed to be responsible for stability and unique physical properties of the $\mathrm{CeO}_{2}$ nanocrystals.

\section{References}

1. S.A.Nepiyko, Physical Properties of Small Metal Particles, Naukova Dumka, Kiev (1985). [in Russian].

2. Yu. Petrov, Physics of Small Particles, Nauka, Moscow (1982). [in Russian].

3. I. D. Morokhov, L.I. Trusov, V.N. Lapovok, Physical Phenomena in Ultra-dispersed Media, Energoatomisdat, Moscow (1984 ). [in Russian].

4. A.I. Gusev, Uspehi Fiz. Nauk, 168, 55 (1998).

5. Z.Zhan, S.A.Barnett, Science, 308, 844 (2005).
6. D.R.Ou, T.Mori, H.Togasaki et al., Langmuir, 27, 3859 (2011).

7. Z.C.Kang, Z.L.Wang, Adv.Mater., 15, 521 (2003).

8. H.Imagawa, A.Suda, K.Yamamura, S.Sun, J.Phys. Chem. C, 115, 1740 (2011).

9. F.Esch, S.Fabris, L.Zhou et al., Science, 309, 752 (2005).

10. P. Maksimchuk, A. Masalov, V. Seminko et al., Nanostrukturnoye materialovedeniye, № 3 - 4 (2013).

11. P.Maksimchuk, V.Seminko, I.Bespalova, A.Masalov, Functional Materials, 21, 254 (2014).

12. P.Maksimchuk, V.Seminko, I.Bespalova, A.Masalov, Functional Materials, 21, 152 (2014).

13. R. C. Evans, An Introduction to Crystal Chemistry, Cambridge University Press, Cambridge (1964).

14. N.Skorodumova, N.Simak, B.Lundqvist et al., Phys. Rev.Let., 89, 1666 (2002).

15. V.M. Apalkov, Yu.I. Boyko, V.V. Slezov Vestnik KhNU ,"Physics ", № 4, 59 (2000).

16. S.P. Timoshenko, J.N. Goodier, Theory of Elasticity, McGraw-Hill, New York (1987).

17. M.P. Slavinskiy, Physico - chemical Properties of Elements, Metallurgy, Moscow (1952). 